\title{
Use of Content Mastery Service Using Role Playing Approach to Improve Student's Emotional Intelligence
}

\author{
Meirizka Liyani Putri ${ }^{1}$, Taufik², Frischa Meivilona Yendi ${ }^{3}$, Verlanda Yuca ${ }^{4}$ \\ ${ }^{1234}$ Universitas Negeri Padang \\ Correspondence author, e-mail: meirizka.liyaniputri@gmail.com
}

\begin{abstract}
Emotional intelligence is the ability possessed by individuals to be able to recognize, understand, manage and manage emotions and understand the emotions of others. There are many problems that arise related to emotional intelligence, especially in the school environment. To be able to overcome this and increase the emotional intelligence of BK teacher students can carry out content mastery services that aim to help students develop and learn new aspects or competencies related to emotional intelligence. Implementation of content mastery services can also be done with a role playing approach by playing the role associated with increasing emotional intelligence.
\end{abstract}

Keywords: Emotional Intelligence, Content Mastery Service with Role Playing Approach

Article History: Received on 15/09/2019; Revised on 15/10/2019; Accepted on 21/11/2019; Published Online: 30/11/2019. distribution, and reproduction in any medium, provided the original work is properly cited. (2019 by author.

\section{INTRODUCTION}

Humans in their development have a task in the form of developmental tasks that must be passed in accordance with the stage of development, especially during adolescence. Where adolescence is the most fun and definitely passed by every individual. At this time there were many conflicts in the adolescents themselves. Fulfillment of the task of adolescent development can be assisted through the educational process both at home and at school. In learning in schools it is often found students find students who cannot achieve their learning achievements despite having high intelligence abilities, while those who have low intelligence abilities obtain relatively high achievements, this is because the level of intelligence is not the only determinant of student success (Aisha, Hamzah, \& Farial, 2017)

Based on the phenomena conveyed above Efendi (2005) explains that intellectual intelligence (IQ) only contributes $20 \%$ to success, while the other $80 \%$ is contributed by other strength factors, including emotional intelligence or Emotional Quotient (EQ) which is the ability to motivate yourself , overcome frustration, control the urges of the heart, set the mood (mood), empathize and the ability to work together. Efendi (2005) also explains that students who have a high level of intellectual intelligence while having a low level of emotional intelligence will be seen as someone who is stubborn, difficult to get along with, easily frustrated, not easy to trust others and is not sensitive to things around and makes them difficult to control his emotions. This is in line with the opinion of Goleman 
(2015) that excessive emotional behavior and negative actions displayed by adolescents, apparently associated with low emotional intelligence.

Emotional intelligence is not a talent, but aspects of emotions within individuals that can be developed and trained, in other words, each individual has been gifted by God emotional intelligence from birth and further depends on how the individual develops the emotional intelligence he has had both by being trained and developed with intensive and use the right methods, methods and time. in the school environment this can be realized by providing content mastery services by BK teachers who are in the school. This is in line with research conducted by Zahro \& Awalya (2018) that content mastery services can help individuals master aspects of the content in synergy where by mastering the content, individuals are able to meet their needs and overcome the problems they are experiencing. .

Content mastery service is one of the types of services that exist in guidance and counseling, this service is a service provided so students can master certain aspects or certain competencies that individuals want to achieve. Content mastery services that can be provided to help improve students' emotional intelligence can be done with a variety of approaches to achieve the desired goals, one approach that can be used by BK teachers is content mastery services with a role playing approach. According to Hamalik (2010) the role playing approach is one of the approaches in learning that is given to students by giving certain roles to students and can dramatize that role in an appearance that can be done in class that gives students the opportunity to do activities or master certain things in active learning activities. The use of the role playing approach in helping to improve students' emotional intelligence is used because basically playing is something that is liked by many individuals, by playing together later students get a lot of lessons learned by increasing their emotional intelligence.

The above is also in line with research conducted by Prihatin and Munir (2016) that through the different roles of students can improve the ability to recognize their own feelings and the feelings of others. They acquire new ways of behaving to overcome problems such as in their role play and can be skills in solving problems. This explains that with the role playing approach students are able to better understand the emotions that exist in themselves, so that children are able to recognize and understand the feelings of others where it is one aspect of emotional intelligence.

\section{THEORITICAL REVIEW}

\section{Emotional Intelligence}

Emotional intelligence is the ability to recognize and control one's own feelings and those of others and use these feelings to guide thoughts and actions (Goleman, 2015). In addition emotional intelligence is useful for monitoring one's own emotions and the emotions of others, to distinguish between various emotions and label them appropriately so that they can be used as emotional information to guide thoughts and behavior (Munir \& Azam, 2017). Furthermore Agustian (2001) explains emotional intelligence is the ability of a person to be able to recognize, feel, understand feelings or emotions in himself or the feelings or emotions possessed by others and effectively apply the emotional sensitivity they have. 
Based on some of the opinions above, it can be concluded that emotional intelligence is an ability possessed by individuals to recognize, understand, and manage their emotions, and can understand and recognize emotions possessed by others who can help the growth and development of the individual's personality. alone.

This emotional intelligence can be realized by the way how individuals are able to give a good impression about themselves, express good emotions about themselves and also other people in their environment. Based on this, Goleman (2015) states that emotional intelligence has five aspects including the following:

1. Recognizing Self-Emotions (Self-Awareness), is the ability possessed by individuals in knowing themselves and is an awareness of their own feelings or emotions.

2. Managing Emotions, is the ability in self-control that is the ability to deal with emotions that arise in him such as controlling anger and anxiety and others.

3. The Ability to Motivate Yourself, is the ability to arrange emotions that aim at controlling yourself, and restraint yourself from various emotions that arise in yourself.

4. Ability to Recognize the Emotions of Others, is the ability to be able to understand others by paying attention to the emotional signs that other people have raised and being able to do what should be done.

5. Ability to Build Good Relationships with Others, is a social skill that supports success in interacting with others that can enable someone to form relationships and influence others both in terms of one's feelings and emotions.

Emotional intelligence is not a talent that is owned by an individual, but one aspect of emotions that exists in the individual itself which can then be developed and also trained by the individual (Susilo, 2018). Based on this, Goleman (2015) explains that there are various factors that influence emotional intelligence itself including the following: 1). Family environment, where family life is the main educator in studying emotions for individuals, where the role of parents is certainly a major factor in the development of children's emotional intelligence, 2). Community environment, where the emotional intelligence of the individual develops in line with the physical and mental development of children that can be obtained by children from the community environment.

\section{Content Mastery Service}

Content mastery service is one of the types of services that exist in guidance and counseling, this service is a service provided so students can master certain aspects or certain competencies that individuals want to achieve. This is in line with what was delivered by Tohirin (2007) content mastery service is an assistance service to individuals (students) both alone and in groups to master certain abilities or competencies through learning activities.

This content mastery service aims to help students master certain content or competencies, especially competencies or habits in doing, doing or doing something useful for their own lives, both in terms of personal, social, learning and career of these students (Zahro \& Awalya, 2018). Content mastery services generally aim to obtain 
certain content for individuals or clients, to add insight and understanding, direct judgment and attitudes, master certain ways or habits to meet their needs and solve their problems where by mastering the content the individual concerned is better able to live life effectively and independently (Juniyarti, Prayitno, \& Marjohan, 2018)

\section{Role Playing Approach}

According to Hamalik (2010) the role playing approach is one of the approaches in learning that is given to students by giving certain roles to students and can dramatize that role in an appearance that can be done in class that gives students the opportunity to do activities or master certain things in active learning activities. Role playing is used by giving a role to students to portray something related to what the teacher wants to do and give (Dinapoli, 2009).

In the field of guidance and counseling the role playing approach is a technique in which individuals portray imaginative and parallel situations with the real world with the aim of helping to achieve self-understanding, improve skills included in the skills to solve problems (problem solving), analyze behavior or show to others how someone's behavior or how someone should behave (Herlina, 2015).

Herlina (2015) also explained that the use of the role playing approach in learning activities provided many benefits to students including: 1 ). Fun and can cause motivation for learning, 2). More learning opportunities to express themselves, 3). Provide wider opportunities to talk, and 4). Can provide fun for students.

\section{DISCUSSION}

Emotional intelligence is the biggest contributor to one's success compared to intellectual intelligence. This is explained by Efendi (2005) that intellectual intelligence (IQ) only contributes $20 \%$ to success, while the other $80 \%$ is contributed by other strength factors, including emotional intelligence or Emotional Quotient (EQ) which is the ability to motivate yourself, overcome frustration, controlling insistence, regulating moods, empathy and ability to work together. Emotional intelligence is the ability possessed by individuals to be able to recognize, understand and manage their emotions, and can understand emotions felt by other people. The problems that arise related to the emotional intelligence of students who are low in number are the number of students who are easily angry and less able to control emotions, are less able to respect others, often joke excessively with friends and others.

The problems that arise will certainly affect the students themselves. This emotional intelligence is a skill that needs to be possessed by individuals to be able to help develop themselves and also the development of their own lives. Based on this, for the scope of the school services that can be provided to help develop and increase emotional intelligence possessed by students is content mastery services. Which is in line with the results of Susilo's research (2018) that an increase in emotional intelligence of grade IX E students at SMP Negeri 2 Gunugwungkal after being given content mastery services. Where before the service of mastering content on emotional intelligence students were still low, where there were still students who were pessimistic, selfishly said harshly, lacked empathy and 
other emotional intelligence problems, but after being given services mastery of content was increased and better than before.

The provision of content mastery services by BK teachers to improve students' emotional intelligence can be done with a variety of approaches, one of which is the role playing approach (playing drama). Role playing is one form of approach that can be used to explain feelings, attitudes, behavior and values, with the aim to live the feelings, angles of the field and the way of thinking of others (Firman, 2018). The role playing approach provides students with the opportunity to explore their ability to be more active in the teaching and learning process and in the use of content mastery services to help improve students' emotional intelligence. (Yuliana, Kristiawan, \& Tatie, 2014). This is in line with Suranto's opinion (2011) that through techniques / role playing approaches, students can improve their ability to respect themselves and the feelings of others, they can learn good behavior to handle difficult situations, and they can practice their abilities in solving problems.

The role playing approach can be implemented in the implementation of content mastery services to improve students' emotional intelligence. Based on the explanation above and also the results of research that have been presented above, service content mastery services to improve students 'emotional intelligence are proven and can increase students' emotional intelligence. In addition, the use of the role playing approach in content mastery services is also effectively used to help improve students' emotional intelligence. This was explained in Zahro \& Awalya's research (2018) that content mastery services with role playing techniques proved to be influential in increasing student empathy in class XI IPS 1 at SMA N 6 Semarang. Where there is an increase from the pre test results included in the low category to the medium category in the post test results. Increasing student empathy indirectly also increases student emotional intelligence because empathy is one aspect of emotional intelligence that exists in individuals.

\section{CONCLUSION}

Based on the discussion above, it can be concluded that the use of content mastery services with the role playing approach to improve students 'emotional intelligence is considered effective and is proven to be able to increase students' emotional intelligence based on previous studies which have also been discussed in the above explanation.

\section{REFERENCES}

Agustian, A. G. (2001). Rahasia Sukses Membangun ESQ Berdasarkan Rukun Iman dan Rukun Islam. Jakarta: Arga.

Aisyah, S., Hamzah, \& Farial. (2017). Efektivitas Layanan Penguasaan Konten Melalui Metode Pembelajaran Simulasi Dengan Teknik Sosiodrama Untuk Meningkatkan Kecerdasan Emosional Siswa Pada Kelas Vii Di Mts Al-Azhar Kec.Alalak Kab.Batola Tahun Ajaran 2017/2018. Jurnal Mahasiswa BK An-Nur : Berbeda, Bermakna, Mulia, ISSN. 2460-9722 , 26-32.

Dinapoli, R. (2009). Using Dramatic Role-Play to Develop Emotional Aptitude. International Journal of English Studies, Volume. 9, No. 2. , 97-110. 
100 Use of Content Mastery Service Using Role Playing Approach to Improve Student's Emotional Intelligence

Efendi, A. (2005). Revolusi Kecerdasan Abad 21 Kritik MI, EI, SQ, AQ E Succesfull Intelligence Atas IQ. Bandung: Alfabeta.

Firman. (2018). Efektifitas Layanan Penguasaan Konten Menggunakan Model Pembelajaran Role Playing Untuk Meningkatkan Kepercayaan Konselor.Jurnal Ilmiah Konseling , 1-8.

Goleman, D. (2015). Emotional Intelligence (Kecerdasan Emosional) . Jakarta: Gramedia Pustaka Utama .

Hamalik, O. (2010). Proses Belajar Mengajar . Jakarta : Bumi Aksara.

Herlina, U. (2015). Teknik Role Playing dalam Konseling Kelompok. SOSIAL HORIZON: Jurnal Pendidikan Indonesia, Vol. 2, No 1, Juni 2015. ISSN 2407-5299 , 94-107.

Juniyarti, M. E., Prayitno, \& Marjohan. (2018). Content Mastery Service: A Help in Related Counseling Problems Students learning Activities. International Journal of Research in Counseling and Education, Volume 01 Number 03 , 43-46.

Munir, M., \& Azam, R. I. (2017). Emotional Intellegence and Employee Performance: An Intervention Based Experimental Study. Journal of Business \& Economics, Volume.9, Number 2 , 1-19.

Prihatin, R., \& Munir, A. (2016). Penggunaan Teknik Role Playing untuk Mengurangi Perilaku Bullying Siswa Kelas XII MIA SMA Negeri 5 Palu. . Jurnal Konseling $\mathcal{E}$ Psikoedukasi, Volume. 1, Nomor.1, 1-10.

Suranto. (2011). Komunikasi Interpersonal. Yogyakarta : Graha Ilmu .

Susilo. (2018). Meningkatkan Kecerdasan Emosional Melalui Layanan Penguasaan Konten Pada Siswa. Jurnal Prakarsa Paedagogia, Volume 1, Nomor 1, 24-34.

Tohirin. (2007). Bimbingan dan Konseling di Sekolah dan Madrasah (Berbasis Integrasi). Jakarta: Rajagrafindo Persada.

Yuliana, Y., Kristiawan, M., \& Tatie, S. (2014). The Effect of Role Play Toward Students' Speaking Skill (an Experiment Study at Grade XI IPA School 1 Batang Anai, Padang Pariaman regency, West Sumatera, Indonesia). The journal of applied sciences research, Volume. 1, Nomor. 4. , 279-283.

Zahro, A., \& Awalya, M. T. (2018). Meningkatkan Empati melalui Layanan Penguasaan Konten dengan Teknik Role Playing. Indonesian Journal of Guidance and Counseling, Volume. 7, Number 2 , 1-6. 